\title{
Academic mentoring projects between disadvantaged children and students. A method for the preparation of students for inclusive school settings
}

\author{
CHRISTINA HEISE* (1) and FRIEDERIKE HEINZEL
}

University of Kassel, Gebäude, Nora-Platiel-Str. 1 (WISO B), 34127 Kassel, Germany

\section{THEMATIC ARTICLE}

Published online: November 11, 2020

(c) 2020 The Author(s)

\begin{abstract}
Future teachers agree to meet a pupil once a week to engage in cultural, social and educational activities within the framework of two mentoring projects conducted at the University of Kassel. The students are supported at the University by an educational science seminar and by professional supervision (Garlichs et al., 2000; Heinzel et al., 2007). At the end of the project the students write a case study. Since 2015 these projects are part of PRONET, a government-funded bundle of various projects in the field of educational research, located at the University of Kassel, which are part of the nation-wide research initiative "Qualitätsoffensive Lehrerbildung". This initiative aims at the improvement of teachers' education regarding inclusion by continuous evaluation of the projects. The mentoring projects promote students' inclusive attitude by stimulating their reflexive and cooperative skills and by raising their awareness for habitus-sensibility. Previous research has shown that mentoring projects can, for example, facilitate teachers' acceptance of heterogeneity of childhood experiences by providing insights into different social environments and by improving reflection on prejudices and stereotypes (Kottmann, 2014; Maas, 2007; Wenzler-Cremer, 2016). Following these findings, the actual research focuses on which kind of reflection students use and if they develop or strengthen inclusive orientations. With regards to data analysis, the qualitative content analysis of the case study is accompanied by sequential interpretation of audio statements, which the students produce at three points in time during their mentoring year. First results show that different kinds of reflection take place, that the students get confronted with inclusive and exclusive inconsistencies, and that they begin to reconceptualize ideas about normality.
\end{abstract}

\footnotetext{
*Corresponding author. E-mail: Christina.Heise@uni-kassel.de
} 


\section{KEYWORDS}

teacher training, mentoring projects, sponsorship projects, reflective learning, case based learning, service learning

\section{INTRODUCTION}

The number of sponsorship or mentoring projects in Germany has been steadily growing since the 1990s. In addition to projects initiated by companies or associations, such projects are also implemented at universities to connect social action and learning. The University of Kassel has been offering sponsorship projects in teacher training for more than 25 years (Garlichs, Petersen, \& Reinert, 2000; Heinzel, Garlichs, \& Pietsch, 2007). Students take on sponsorship for a child for two semesters and are thereby accompanied by a university seminar and professional supervision. At the end of the projects, the students write a scientifically substantiated case report about the mentored child. The sponsorship programs make it possible to link theory and practice as well as cooperate with institutions from civil society to facilitate Service Learning. Beginning in 2015, the university of Kassel has implemented the concept "PRONET - Professionalisierung durch Vernetzung" within the scope of the "Qualitätsoffensive Lehrerbildung" and the sponsorship programs have been located under this umbrella ever since. ${ }^{1}$ The projects were restructured and continuously evaluated over the course of PRONET. This article outlines the format and objective of the sponsorship projects and also provides insights into its evaluation. First, the educational policy background in Germany is illustrated to clarify the societal context of the sponsorship projects. Following this, the structure, process and intention of the projects, as well as the theoretical background, are described. Finally, after describing the current state of research, the ongoing evaluation of the projects and selected results are presented.

\section{EDUCATIONAL POLICY DEVELOPMENTS AND UNEQUAL EDUCATIONAL OPPORTUNITIES}

The school and educational system, and thus teacher training in Germany, have been discussed for some time now and are currently undergoing structural and content-related changes. On the one hand, the results of international school performance studies such as PISA or IGLU were perceived as being alarming for Germany, on the other hand the need for action regarding the German school and educational system stems from the UNESCO Salamanca Declaration of 1994 and the UN Convention on the Rights of Persons with Disabilities of 2006. With the signing of the UN Conventions, the educational system faces the task of implementing inclusion at all levels. The debate in Germany distinguishes between a "narrow concept of inclusion" and a "broad concept of inclusion". While the "narrow concept of inclusion" within the school context refers to those who have officially recognized special education needs, the "broad concept of

\footnotetext{
${ }^{1}$ The project on which this report is based was funded as part of the joint program "Qualitätsoffensive Lehrerbildung" of the Federal Government and German Länder with funds from the Federal Ministry of Education and Research under the funding codes 01JA1505 (PRONET) and 01JA180 (PRONET ${ }^{2}$ ). The responsibility for the content of this article lies with the authors.
} 
inclusion" aims to incorporate different dimensions of heterogeneity (Löser \& Werning, 2015). Inclusion then follows a broad conception of the addressees, focuses on "all" characteristics of diversity and simultaneously addresses vulnerable groups to provide all children with equal educational opportunities, access to education and social participation. The aim is to maximize social participation while minimizing discrimination (Ainscow, Booth, Dyson, Booth, \& Dyson, 2006). People who are endangered or affected by marginalization are also included (Katzenbach, 2015).

Such an understanding of inclusion is also claimed at the international level.

"In several countries, inclusion is still thought of simply as an approach to serving children with disabilities within general education settings. Internationally, however, it is increasingly seen more broadly as a reform that supports and welcomes diversity amongst all learners. It presumes that the aim of inclusive education is to eliminate social exclusion resulting from attitudes and responses to diversity in race, social class, ethnicity, religion, gender and ability."

(UNESCO, 2008, S. 5)

While on the one hand social and educational policy discourses and objectives pursue a claim to inclusion and the educational system is based on the meritocratic principle, it becomes repeatedly clear that educational opportunities are unequally distributed and closely linked to social class (Andresen \& Neumann, 2018). Individualizing factors are used far too often instead of taking institutional and structural results into account (Panagiotopoulou \& Winter, 2019). Studies prove the existence of mechanisms of "institutional discrimination" (Gomolla, 2003) and there are findings pointing to tendencies of homogenization regarding the pupils and the associated selection processes in the German school system (Tillmann, 2007). In addition, empirical studies show that interactional aspects play an important role in everyday school life. Thus, the interactions between teachers and pupils can contribute to an educational disadvantage due to their different habitus (Lange-Vester \& Teiwes-Kügler, 2014).

\section{The professionalization of teachers in Germany}

The unequal distribution of educational opportunities, the necessity to implement inclusion into everyday school life, and the poor results of school performance studies have not only led to changes in the field of school and curriculum development in Germany in recent years, but teacher training has also undergone structural and content-related changes. In this context, the Kultusministerkonferenz formulates "Standards für die Lehrerbildung für die Bildungswissenschaften" and specifies various requirements that teachers should fulfil (Kultusministerkonferenz, 2014). Reflection and multi-professional cooperation are defined as skills which play a central role in the professionalization of teachers, both on a whole, and in view of inclusive school settings in the different areas of competence developed by the Kultusministerkonferenz (Hochschulrektorenkonferenz \& Hochschulkonferenz, 2015). The tremendous importance attributed to teachers regarding a successful educational system is underscored by the Federal Government and federal states through the "Qualitätsoffensive Lehrerbildung", under which 59 universities in all federal states have been supported with up to 500 million euros since 2015 for pursuing a lasting improvement and raising the institutional profile of teacher training. ${ }^{2}$ In that

${ }^{2}$ https://www.qualitaetsoffensive-lehrerbildung.de/de/programm-50.html. 
regard, new learning environments at German universities have been continuously developed and evaluated since 2015 to modernize teacher training and better prepare student teachers for their subsequent professional requirements. Since 2015, the University of Kassel has implemented the concept "PRONET - Professionalisierung durch Vernetzung" as part of the "Qualitätsoffensive Lehrerbildung". The main goal in one of the three areas of activity of PRONET is to expand the inclusion-related courses offered at the University of Kassel to promote reflexive and action competencies for inclusive school education (Heinzel \& Garlichs, 2007). The sponsorship projects are located in this area. Their conception was modified in such a way that inclusion forms the main content-related focal point. In addition, a discussion takes place regarding the diversity of today's childhoods and the different chances children haveto participate in education. The sponsorship projects are supposed to contribute to the professionalization of students and prepare them for inclusive school settings through the promotion of reflection and cooperation skills and the sensitization for divergent habitus formations.

\section{THE SPONSORSHIP PROJECTS “PROJEKT K” AND "KULTUR KIDS NORDSTADT"}

"Projekt K" (K stands for the German words of children in Kassel, for cooperation and continuity) was founded by Ariane Garlichs in 1993 as one of the first sponsorship projects in German teacher training under the name "Kasseler Schülerhilfeprojekt" and has since been restructured several times. The project cooperates with the "Familienberatungszentrum" and the "Beratungs-und Förderzentrum" in Kassel, which refer children "in special circumstances" to the project. In 2007, the project was awarded the second place in the Hessian University Prize for Excellence in Teaching ("Hessischer Hochschulpreis für Exzellenz in der Lehre"). The project "Kultur Kids Nordstadt" was launched in 2008 as part of a seminar and cooperates with schools in Kassel who are located in a disadvantaged district. Children with an immigration background are referred to the project through these schools. The projects start in the winter semester and encompass two semesters. They can be attended as a core module in the educational science part of the teacher training program. The students write a case report containing observations about the child and scientific analyses of these observations as the final module examination.

The students meet their sponsored child every week for joint activities as part of the projects. Due to their individual circumstances, the children participating in the projects do not experience social participation to the same extent as other children of their age. This lack of participation can, for example, be due to the socio-economic situation of their families, other family languages than the school language German, sickness of the parents or disadvantages caused by handicaps/disabilities. The sponsorships are intended to give these children access to cultural, social and educational areas which would otherwise remain closed to them because of their social situation. They are assigned an extra-curricular and extra-familial caregiver who focuses entirely on them and their needs. Thereby, the self-confidence of the children and their individual development are to be promoted.

The students act on their own responsibility within the framework of their sponsorships. Contact with the cooperation partners, teachers, parents, and other actors from the children's living environment, such as therapists, social workers etc. enables the students to take an integral view on the everyday life of the child and to include different perspectives. On the one hand, 
they have the chance to build a trusting relationship with the child based on appreciation and on the other hand they have the opportunity to practice keeping a professional distance and gain experience in the field of multi-professional cooperation. However, they should not see themselves as merely another actor in the child's life, but rather approach it from an ethnographic research perspective. During the entire sponsorship, they write a field diary which, in addition to describing the respective activities, also documents the examination of their feelings, perceptions, actions and attributions. The actions and perceptions of the students in the context of their practical experiences and interactions with the child and its living environment are also reflected within the framework of the university seminar and supervision, which take place during the semester and switch weekly. In this way the experiences can be theoretically analyzed and there is an opportunity for self-reflection.

\section{AIMS OF THE SPONSORSHIP PROJECTS REGARDING THE PROFESSIONALISM OF THE STUDENTS}

The sponsorship projects pursue a concept of professionalism which aims at promoting or strengthening inclusive attitudes among students. They focus on raising awareness for the diversity of children's living environments and professionalism in dealing with heterogeneity (Garlichs et al., 2000; Heinzel et al., 2007). Students oftentimes adopt a skeptical attitude towards heterogeneous learning groups at the outset of their teacher training and take the view that "heterogeneity doesn't work" (Erhardt \& Breyer, 2013, S. 3). At the same time research shows that an inclusive attitude and the ability to deal with heterogeneity have to be understood as central tasks of teacher training (Heinrich, Urban, \& Werning, 2013; Lotze \& Kiso, 2014). Educational science discusses what is to be understood by a professional-pedagogical attitude from a historical, empirical and theoretical perspective (Schwer \& Solzbacher, 2014). While the concept of "professionalization" refers to processes, "professionalism" or "professional attitude" is more about an action-based theoretical determination. The ability to reflect is central for pedagogical discourse in the context of such an action-based theoretical approach to the concept of professional attitudes. It is emphasized that reflection is linked to social processes and is always activated when there are breaches of habits and behavioral routines (Schwer, Solzbacher, \& Behrensen, 2014, S. 54). The relevance of reflection is underscored in all profession-theoretical approaches and is considered to be a key competence in the context of the professional activity of teachers (Häcker \& Walm, 2015; Wyss, 2013). Reflection is seen as indispensable to strengthen and promote inclusive attitudes within the scope of the sponsorship projects. Previous research has shown that mentoring projects can, for example, facilitate teachers' acceptance of heterogeneity of childhood experiences by providing insights into different social environments and by improving reflection on prejudices and stereotypes (Kottmann, 2014; Maas, 2007; Wenzler-Cremer, 2016).

\section{Reflections in the sponsorship projects}

Häcker and Walm (2015) comprehend reflection as the habitualizing of (self-)referential forms of thinking (Häcker \& Walm, 2015, S. 82) and distinguish between two lines of reasoning to justify the necessity for reflexive learning within the context of teacher training. One line of reasoning justifies the necessity for reflection with contradictory social structures and the 
associated uncertainties in pedagogical action (Helsper, 2002), while the second line of reasoning highlights the relationships between knowledge and action or theory and practice, and understands reflection as a mediating element (Combe \& Kolbe, 2008; Herzog, 1995). Both lines of reasoning are important within the scope of the sponsorship projects.

Schön (1984) developed the concept of the "reflective practitioner" in the 1980s which conceives of the teacher as a person who continually questions and develops his own action. Pedagogical interactions should be reflected before, during and especially after the action. The actions should be questioned as to their appropriateness regarding the situational and casespecific circumstances.

Students analyze their interactions with the children and also observe the actions of other participants (e.g., parents, teachers, social workers, therapists) in the sponsorship projects. They are asked to question why they themselves and other actors involved act in this way and based on which biographical experiences they themselves interpret the action situation. In that regard, students reflect on their perception of the living environment of the child and oftentimes contrast it with their own conditions of growing up. Thereby, the students have to examine their habitus-related assumptions and ideas and are encouraged to question their location-boundedness as well as the associated attributions and patterns of perception. According to Aepli and Lötscher (2016), the object of thought to which the reflection refers can concern one's experiences or practice, but it can also refer to knowledge, information, theories, interpretations as well as one's or other people's ideas and assumptions. Reflection then consists of the critical examination of something that is believed to be true. The experiences, assumptions and interpretations are supposed to be questioned. In doing so, possible conclusions and future measures are critically reviewed. Patterns of experience can thus be made conscious and questioned, thereby opening up the possibility of recognizing that the perception and evaluation of certain life plans, practices and attribution patterns in a specific situation are shaped by the individual's own living conditions and biography.

Häcker (2017) emphasizes that reflexive learning involves a relational task that consists of combining practical and scientific learning. In the process, subjective theories and one's own practice have to be questioned against the background of pedagogical theory. He distinguishes between three forms of reflection: structural reflection, theoretical reflection and self-reflection. The sponsorships social and school structures are analyzed in addition to the already described self-referential, biographical reflections and are then related to the living conditions of the sponsored child and the practical experiences with her or him. This is promoted by the fact that the students in the university seminar engage with scientific knowledge and knowledge of structural reproduction mechanisms of inequality and institutional discrimination (Gomolla, 2003). They are supposed to recognize the constructive character of social categories and their power of interpretation. This knowledge can enable the students to perceive the living environment of the child from a new point of view and also rethink their own social position. According to Häcker (2017), theoretical reflection is understood as a reflection with reference to scientific findings and results. These become accessible to the students through the work in the seminar. This outside knowledge introduces other perspectives into the discussion and creates the prerequisites for transcending the known and familiar (Häcker, 2017). The students relate scientific theories to their practical experience and reflect on their appropriateness. Theoretical work focuses on scientifically sound justifications, concepts and findings in connection with processes of social and educational inclusion and exclusion. The intention in regards to 
structural obstacles and individual attributions of meaning in relation to inclusion and heterogeneity is to "disclose them, point them out, to take a stand, to demand extended dispositions over the conditions of one's actions if necessary or to take initiatives to do this together with others in processes of social transition to independence" (Häcker, Berndt \& Walm, 2016; own translation).

Ultimately, with reference to Korthagen and Vasalos (2005, 2010), reflection can be understood as a mental process in which a social situation or existing knowledge is structured or restructured to build new mental knowledge structures. Following this cognitive-psychological perspective, behavior is based on mental structures that are produced by experiences and confrontations with situations and that can be influenced through reflection. It is also assumed here that meaning and attribution can be changed through reflection.

A central objective of the sponsorship projects is the (re)structuring of attitudes and convictions. On the one hand, positive attitudes of students towards inclusion and dealing with heterogeneity are supposed to be developed through the reflexive linking of theory and practice as well as the connection and intertwining of the various forms of reflection. On the other hand, different forms of reflexive thinking are supposed to be identified as an integral part of pedagogical action and a reflexive professional habitus. Various building blocks are central in the context of the sponsorship projects which are intended to stimulate reflection and contribute to professionalism.

\section{Crucial building blocks of professionalization in the sponsorship projects}

The sponsorship projects pursue the professionalization of students based on various building blocks: 1. Practical experiences with the sponsored child and its living environment, 2. Cooperation with information centers and parents, 3. Accompanying seminar and supervision, 4. Ethnographic view on the child's living environment and writing of a field diary which also forms the framework for 5 . The final case report.

The ethnographic research assignment. The students are supposed to consider themselves ethnographic researchers over the course of the sponsorships. Based on ethnography as a practice of field research (Breidenstein et al., 2015) and in the context of ethnographic childhood research (Lange \& Wiesemann, 2012), the (everyday) living environment of children can be understood as a "self-spun web of meaning" (Geertz, 1983; S.9). The aim is to look at the children's perspectives by extrapolating their practices and attributions of meaning. Through the use of participatory observation, the students are supposed to learn to understand the viewpoints of the children, because "we can only make accessible through questioning, observation, reflection and debate on how children experience and process the world" (Friebertshäuser \& Panagiotopoulou, 2010; S. 305; own translation). The ethnographic perspective is supposed to enable students to get access to the children and help them to free themselves from their own preexisting assumptions and attributions or to reflect on them. Furthermore, this methodological approach can be used to make students aware of the historical, cultural and social boundedness of life models, practices and patterns of interpretation and to realize their relativity. The sponsorship or the living environment of the child thus becomes a field of research for the students which already provides insights into the research practice during their studies (Pietsch, 2009) and requires reflexivity.

The case report. Part of the research strategy of ethnography is to keep a field diary. In this field diary, students record their encounters with the child throughout their sponsorship and describe 
their own views, assumptions, perceptions and uncertainties. These field notes form the framework for the final case report that has to be written as an examination performance after the end of the sponsorship and selects an aspect from the living environment of the child as the main topic (e.g., poverty, physical barriers, language barriers, migration, etc.). Students work on their chosen topic for the case report against the background of their field notes and autonomously search and review proper theoretical literature. In doing so, the story of the child is supposed to be told in a professional and respectful way (Heinzel, 2007). Following the model structure according to Heinzel (2007), the case report is divided into the following parts: 1. Introduction and leading question, 2. Theoretical background, 3. Description of the research methods, 4. Profile of the child, 5. Process sequence, 6. Interpretation regarding the main topic and research question, 7. Summary and theory-based discussion of the results, 8. Bibliography. The heading "process sequence" prompts students to make their relationship to and perception of the child, their perspectives, assumptions, and developments transparent. In addition, they are expected to evaluate the specific case of the child they sponsored against the background of the school and social inclusion efforts.

When preparing the case report, the students always dealt with both the child and themselves.

Continuous documentation and reflection on their development within the framework of the field diary helps to develop an awareness of the subjectivity of their perceptions and attributions, as well as the impact of their socio-cultural boundedness and relativity. At the same time, students are expected to deal with scientific theories and research results on a topic-related basis, thus creating a scientific detachment from the practice in the sponsorships. The scientific work is supposed to enable a linkage between theory and practice and the frequently described "notorious tension" between theory and practice in the literature ought to be transformed "into a fruitful relationship between academic knowledge and professional capabilities" (Pieper, Frei, Hauenschild, \& Schmidt-Thieme, 2014, S. 9; own translation).

Students are given the opportunity to detach their observations from the sponsorship of subjective theories and personal assumptions and to place them in a scientific frame of reference through the required engagement with theory. Helsper (2002) points out that students cannot directly transfer the scientific knowledge acquired during their studies onto their practical work because the individual case must always be taken into account in everyday school life. Understanding the individual case becomes even more important in connection with the pursuit of inclusive goals. It is precisely this engagement with individual cases that is made possible in the sponsorship projects and in the case report in particular. The case work aims - as emphasized by Pieper et al. (2014) as being pivotal - at increasing the reflexive competence regarding one's actions as well as the ability to reconstruct action practices and develop interpretation practices. Apart from overcoming the so-called theory-practice problem, the habitus-forming function is highlighted as an important intention of case work in teacher training (Reichertz 2014). Other authors speak more specifically of a researching habitus (Pieper et al., 2014) or a reflexive habitus and thereby underscore the pivotal role of the development of reflexivity through case work for professionalism and professionalization (Lüsebrink \& Grimminger, 2014). The conduct of field and case studies within the framework of the ethnographic approach supports the pedagogical practice in the sponsorship projects.

The cooperations. In addition to its contribution in conveying the theory-practice problem, experience with (inter-)professional cooperation can also be gained within the framework of 
the sponsorship projects. Families, schools, information and support centers, actors in child and youth welfare as well as therapists, and students can grasp different perspectives on the child they are accompanying as a result of these cooperative experiences within the nexus of action between sponsorship projects. Thereby, both the assessments of cooperation partners can be questioned and the blind spots of one's pedagogical action revealed. "Personal schemes can be questioned, which is supported through alternative points of view. Incongruence experiences change patterns of action." (Berkemeyer, Järvinen, Otto, \& Bos, 2011, S. 228; own translation).

Cooperation is regarded as an essential element of an inclusive school setting within the context of inclusive educational aspirations. The ability of teachers to engage in multi-professional cooperation as a significant component of professionalism is currently being discussed against the background of the inclusionary claim (Boller, 2012, S. 205). Teachers are supposed to cooperate with each other and with other professions to optimally promote the individual development processes of school students in an inclusive school setting (Fabel-Lamla \& Reinecke Terner, 2015). The necessity of cooperation in an inclusive school setting was theoretically analyzed in the sponsorship projects, the experiences with cooperation was discussed and their chances and limits were reflected upon.

The scientific seminar and supervision. There are 13 seminar sessions and equally as many supervision sessions, each lasting 90 minutes. Furthermore, there is the opportunity for individual supervision.

Within the scope of the seminar, the students are initially instructed via an introduction of ethnography and the preparation of small ethnographic observation assignments to help approach the living environment of the child with an ethnographic research perspective. Aside from the case specific topics arising from the sponsorship, which the students introduce into the seminar, the focus is on the topic of "inclusion". Students are taught the historical and legal foundations of inclusion and discursive threads are also discussed. Guest contributions from cooperation partners provide insights into the practice of inclusion. Building on this, tensions and contradictions in dealing with inclusion and exclusion are discussed. Different dimensions of heterogeneity are analyzed and the demand for a diversity-sensitive pedagogy is discussed. Moreover, aspects of the reproduction of social inequality, equal opportunities, and educational disadvantage are presented with a focus on the contribution of schools to the reproduction of educational disadvantage. The competences regarding the ability to reflect and cooperate, which are emphasized in the context of inclusion, are explicitly dealt with. Finally, the term "habitus" is discussed and the concept of "habitus sensitivity" is addressed. As preparation for the sessions the students read selected texts and prepare the respective seminar session with the help of tasks or guiding questions. This creates a common knowledge base for discussions. Students are also encouraged to relate the findings to their personal experiences obtained during the course of the sponsorships. The same question is repeatedly asked: What is it like with your child? In this way, the living environments of the accompanied children are introduced into the seminar, vividly reported and reflected on through academic theory.

Students are also given the opportunity to deal with personal problems, uncertainties or role conflicts in the supervision sessions. They can become aware of their own expectations and reflect on experiences in an individual or group supervision setting. Not least, supervision offers the opportunity for guided self-reflection. 
Students are generally not experienced in supervision and they usually come into contact with a supervision process for the first time. Therefore, at the first meeting they receive basic information on what supervision means and how supervision can be used for sponsorship. The approach of "Systemic Supervision" is presented with an explanation of the use of the term "system" and the ideas regarding the interaction between person, role, function, assignment and organization within the context of Systemic Supervision. It is also pointed out that "Systemic Supervision" is solution and resource-oriented. In Systemic Supervision the participants are regarded as self-responsible experts of their own person and actions. The supervisor introduces an external perspective into the sponsorship relationships, whereby new individual, professional and institutional questions can be developed and interactions, patterns and processes can be made visible. The aim is to increase the possibilities of thinking and acting and to be able to develop new approaches to solutions by broadening the viewpoint.

\section{THEORETICAL BACKGROUND}

Now that the structures of the sponsorship projects, their objectives and the building blocks for achieving them have been presented, the profession-theoretical background is presented. Here, the structural-theoretical and biographical approaches to determining teacher professionalism are essential. The structural-theoretical approach assumes that teacher action is permeated by fundamental tensions. These antinomies of teacher action result from progressive processes of reflexive modernization and new demands for reflection and action on the part of teachers (Helsper, 1996, S. 521). The ability to deal with these contradictions and the associated uncertainties in the everyday actions of the teacher then denotes professionalism in the structuraltheoretical approach (Terhart, 2013). Helsper distinguishes eleven areas of tension at the level of the "constitutive, not rescindable, but only reflexively manageable antinomies of the teacher's action" with his focus on the structural constitution of teacher action" (Helsper, 2002, S. 76; own translation). The focus is primarily on subsumption antinomy and differentiation antinomy in the context of the sponsorship projects. The subsumption antinomy describes the tension between the reconstruction of the individual case on the one hand and the subsumption of the individual case under scientific and theoretical categories on the other. While on the one hand the logic of action is based on superordinate classifications and categorial assignments, teacher's actions must also do justice to the specific logic of the individual case. The situation is similar with the differentiation antinomy, which describes the tension between the homogenizing, generalizing equal treatment of all school students and the necessity of differentiating school students (Helsper, 2002). These tensions can become particularly intense in the context of inclusion (Frey \& Buhl, 2018). Reflection becomes a means of overcoming uncertainties and contradictions in the structural-theoretical position, because "especially the self-critical, reflective turning back to one's actions, to one's professional development is a crucial motor for the advancement of professional skills." (Terhart, 2011, S. 207; own translation). While Helsper on the one hand carves out the different antinomies in a structure-related way, he on the other hand makes it clear that "there is no possibility, independent of the specific person, the respective self, the respective professional biography and the professional habitus to formulate an ideal conception or a 'model' of the professional teacher." (Helsper, 2002, S. 95; own translation). The respective ability of the teacher to deal with the different antinomies and to tackle them in the 
long run within the framework of a professional habitus is always influenced by the individual biography and the engagement with it, because "the ideal 'quality' of pedagogical action is reached by teachers through different paths and different structural variants with which they locate themselves within the tension field of antinomies." (Helsper, 2002, S. 96; own translation). Helsper's structural-theoretical approach overlaps with aspects of the biographical approach for professionalizing teachers at this point.

The biographical approach supplements the debate on professionalization with an individual perspective and regards professionalization within the framework of professional biographical developments as an ongoing process. It is assumed that the biographical experiences, ties and meanings within the family and the milieu of origin are also of importance for professional socialization (Fabel-Lamla, 200606). Following the biographical approach, private and professional life cannot be thought of independently of each other (Herzog, 2011; Terhart, 2013). The individual accumulation of experience results in specific biographical resources and risks. From a biographical perspective, it is asked

"how teachers subjectively experience the contradictory requirements and core problems of professional action, how they deal with the associated demanding balancing and reflection requirements on a case-by-case basis and which biographical resources, dispositions and experiences prove to guide orientation and action" (Fabel-Lamla, 2018, 91; own translation).

In this approach, the influence of one's experiences on one's professional actions and selfimage can be made visible or linked through reflection. Reflection is essential in both the structural-theoretical and biographical professions approach.

\section{EVALUATION OF SPONSORSHIPS IN TEACHER TRAINING}

In recent years, various German universities have initiated sponsorship or mentoring projects in teacher training. While a large number of studies on mentoring projects have been published in the Anglo-American region, only a few results are available from Germany. The research activities usually focus on the effect of sponsorships on the children involved. Initial research results regarding the effect on mentors in the context of teacher training show that such projects are suitable for breaking down stereotypes among students and providing insights for them into the world of children. Furthermore, they can sensitize them for topics such as disadvantage, learning difficulties and requirements in dealing with heterogeneity. Different attitudes and patterns of action on the part of student teachers could be identified, which point to a more pronounced orientation towards opportunities and problems as well as the ability to act and an expanded horizon of understanding (de Boer \& Schwiderski, 2018; Kottmann, 2014; Maas, 2007; Müller-Kohlenberg, 2018; Wenzler-Cremer, 2016).

\section{Previous evaluation of sponsorship projects at the University of Kassel}

There are already several scientific studies on the Kassel sponsorship projects available. Ariane Garlichs et al. (2000) vividly describes the students' access to the world of children and points out the benefits for their future profession. Pietsch (2010) reconstructed three concepts based on narrative interviews concerning the accompaniment of children by student sponsors. The experience-oriented concept aims at observing, advising and attentively accompanying the 
children. At the same time, the students also want to be needed. The participation-oriented concept is oriented towards the individual needs of the children and focuses on their participation. An area of tension is that autonomous development cannot always be granted. The result-oriented concept is located between efforts of support on the one hand and raising one's profile or qualification on the other (Pietsch, 2010, S. 208ff.). Further evaluation of the Kasselbased "Projekt K" was carried out based on an online questionnaire with which former participants were asked about their assessments retrospectively. Interviewees mentioned the following benefits which they gained from the project: high learning output, even in comparison to other university programs or seminars; the ability to grasp, recognize, acknowledge and reflect upon heterogeneity (Alexi, Romba, \& Heinzel, 2016). What is particularly interesting here is that the students were surveyed retrospectively, and this allows for conclusions to be drawn regarding the sustainability of the projects. A comparison of text-based case analyses and casework in which students themselves are acting directly with the child shows that in a frame of text-based case studies the students focus on the situation itself whereas in the casework in which they are directly involved, they focus on the process in the sponsorship projects (Alexi, Heinzel \& Marini, 2014).

\section{Current evaluation of projects in the context of PRONET}

The projects are currently being evaluated in the context of the "Qualitätsoffensive Lehrerbildung". The case reports are analyzed based on a category system using the summarizing content analysis according to Mayring (2010). The focus of the analysis is on the reflections made and the cooperation experiences of the students. In addition to the case reports, the students submit audio statements at three points in time during the sponsorships. Those are then interpreted sequentially, reconstructing the (habitus-related) orientations and attitudes of the students.

Approximately 40 case reports are going to be evaluated over the course of the "Qualitätsoffensive Lehrerbildung", each of which includes three audio statements. The previous analyses refer to the first part of the case reports. The categories of analysis have been developed and initial results are available.

\section{Evaluation of the case reports}

The evaluation of the case reports was initially based on a deductive category system, which was theoretically developed based on the focal points of the accompanying research (reflection, cooperation, and inclusive attitudes). The deductively constructed category system was enhanced by inductively formed subcategories based on the empirical material after reviewing parts of the case reports. The case reports were coded by two persons independently of each other to ensure reliability. The following overview gives an insight into the categories and thus into the topics which were coded in the course of the evaluation of the case reports (See Table 1).

\section{Results of the analysis regarding the reflections of the students}

Biographical self-referential reflections, as well as structural and theoretical reflections can be distinguished in the evaluation of the case reports, which indicates a rethinking or new thinking or even a restructuring of assumptions and patterns of interpretation among the students. This is specified in the following based on selected text passages. 
Table 1 .

\begin{tabular}{ll}
\hline K1 & Establishment of biographical references \\
\hline K2 & View on own actions \\
K3 & View on the child's actions and abilities \\
K4 & View on the child's living environment \\
K5 & Examination of school and institutional contexts \\
K6 & Experiences with cooperation \\
K7 & Examination of inclusion \\
K8 & Assessment of project experience \\
K9 & Normalizations \\
K10 & Experiences of failure and powerlessness \\
K11 & Articulation of false expectations in the field \\
K12 & Criticism of society and politics \\
K13 & Reflections on own roles \\
K14 & Motivation \\
K15 & Establishment of theoretical references \\
K16 & Seminar feedback \\
\hline
\end{tabular}

Biographical self-referential reflections. Text passages from the case reports are assigned to the biographical self-referential form of reflection, in which the students refer to their biography, question it and use it as an explanatory background for their individual assumptions and foils of perception. The following excerpt documents the reflection of one participant's convictions: "In retrospect I sadly have to admit that I am not completely free from (discriminating) prejudices, although I always thought this of myself." (own translation).

The students also address the process-like development in the course of the sponsorship:

"Viewed in this light, I also caught myself showing no respect and appreciation for the living environment in which $\mathrm{X}$ lived and this was due to my ethical values, my own experiences and prejudices. The fact that I was able to really see with my own eyes and get to know his family and the living conditions and that at the same time I was shown by school visits that these circumstances are not an isolated case, considerably increased my respect for other living conditions." (own translation).

The students also reflect on their location-boundedness and recognize that this influences their own perspective: "I am aware that the analysis of this condition is based on my very limited personal perception." (own translation). The area of self-referential reflections also includes text passages that deal with the living environment of the child itself and point to an opening towards inclusive attitudes: "[...] I have become more sensitive and have turned my attention away from the comparison between our living environments and towards the child in its uniqueness." (own translation).

By and large, all the case reports analyzed so far reveal text passages that point to the fact that the students deal intensively with their points of view and also critically examine, relativize, correct or expand them in the course of the project. Thereby, oftentimes the perception of the child itself is central: "I myself am shocked that I could think that as a socially committed person I was doing a favor for a person in need and enriching his life. I'm ashamed for thinking this way." (own translation). 
Structural and theoretical reflections. The section on structural reflections includes text passages in which students deal with the social and school-based dimensions of inequality. These are associated with limited opportunities for participation and are partly attributed to the children, as the following excerpt shows: "At the same time, it should not be forgotten that X certainly has a disadvantage due to his lack of knowledge of the German language and does not always understand what is explained to him." (own translation). The analysis of the case reports suggests that the students associate inclusion with participation and argue structurally to capture inequality. They include various theoretical structural levels as well as scientific findings in their discussions. It is pointed out, for example, that the quite high-performing sponsored child, unfortunately, has fewer educational chances, "because it could be empirically proven that educational success and failure are not only conditional on individual performance." (own translation). Simultaneously, reflections can be found in the case reports that indicate a sensitization regarding disadvantages and discrimination at the micro-level, as the following example shows: "Besides, there have been occasional discriminatory comments from a teacher that rule out appreciation and respect for other ways of life." (own translation). Structural and theoretical reflections can be found in particular when the focus is on the child's living conditions within the context of its social discrimination.

Text passages in which theoretical knowledge is used to sharpen or clarify relationships are coded as theoretical reflections. Theoretical and structural reflection are oftentimes combined, as is shown in the following excerpt: "In reference to Bourdieu's model of the reproduction of social inequality a graduation certificate from this school would thus mean a low economic capital and thus a low cultural capital for X, but also for subsequent generations." (own translation). Critical assessments of survey instruments can also be found within the theoretical reflections: "A deficiency perspective, which in part can be found within research, should thus be explicitly avoided." (own translation).

There are also reflections on the fundamental structural tensions of pedagogical action, which can become exacerbated within the context of inclusion. The students are confronted with the conflicting expectations of pedagogical action within the living environment of the sponsored children, can observe them and are forced to deal with these contradictions, as the following excerpt shows:

"This shows me that the school does not have the necessary resources to provide individual assistance for all these children. Of course, inclusive schooling is not primarily about individual support, but about the joint teaching of all children. (...) In my opinion, the teacher, unfortunately, did not engage in any form of differentiation. All children should work on the worksheets and exercise books at the same pace, without showing interest in those children, that were slower than others or had not understood something." (own translation).

Reflection on reflection. In the course of the evaluation, text passages are also coded in which the students themselves reflect on a topic:

"This is certainly beneficial for my professional future as a teacherwithin a multicultural and pluralistic society and especially showed me that one has to reflect situations over and over again in order not to be guided by prejudices and stereotypical images." (own translation).

It can be seen that a majority of students recognize the relevance of reflection and emphasize it, especially regarding their future professional activity. In doing so, they often refer to inclusive aspects: "In particular, the reflection of one's standpoint and the appreciation of other 
perspectives and living environments for me seems to be an important conclusion." (own translation).

A large number of text passages referring to reflections could be coded in the ongoing evaluation of the case reports. The focus is therefore on biographical or self-referential reflexions. The theoretical reflections are primarily focused on social and school structures that generate educational disadvantages and restrict social participation. Theoretical reflections are often directly related to the child and its living environment. Students additionally reflect on the value of the projects as a whole for their personal development.

Analysis of the audio statements. Apart from the case reports, the students submit audio statements at three points in time in which they answer given questions in a kind of selfinterview.

The first statement is made by the students before they get to know the child, the second about halfway through the sponsorship and the final statement after the case report has been drafted. The audio statements serve both as evaluation tools and as support for the students' selfreflection. The fact that some of the students refer to the previous statements without being asked as well as comment, supplement and relativize previous views and assumptions, makes it clear that this is successful.

The audio statements are analyzed sequentially. Thus, interaction processes are evaluated. The reconstruction focuses on mentality and habitus structures in the sense of implicit inclusive or exclusive knowledge structures that guide action. The analysis focuses specifically on the orientations with which students enter the sponsorships and whether these potentially change. At the same time, the interpretation focuses on the discourses that the students follow in their speech acts. Following the habitus reconstruction according to Kramer (2017) the structuring of habitus as a generating principle of action is itself explored. The knowledge stocks located in the habitus are the modus operandi or the generative principle that produces action and life practice in a specific way. Habitus is to be understood as implicit knowledge, each with its structures of meaning and connection to an individual life practice. Following Kramers (2015) methodological reasoning, habitus reconstruction enables methodological access to realms of experience and their implicit knowledge stocks.

Findings within the context of the audio statements. So far, two essential cases have been reconstructed in detail. The reconstruction of the audio statement of a student (student D) showed that the student recognizes "normality as a construct" on the one hand, but at the same time is strongly oriented towards the inclusive seminar discourse, or at least clings to it. In a second case interpretation (student B) it was found that the student starts the sponsorship project with a deficiency perspective regarding the children and therefore searches for "what is wrong with the child". In the course of the sponsorship, she reflects on her perspective and distances herself from the attitude she adopted at the beginning of the sponsorship (Heise \& Heinzel, 2020).

Methodologically, it can be seen that a combination of the reconstruction of audio statements and case reports promises interesting results. It remains unclear to what extent students adapt their reflections and how sustainable their learning experiences are in light of the project's goal to promote reflective and inclusive attitudes. 
Comments on the evaluation results. First of all, it must be emphasized that the evaluation has not been completed and therefore only tendencies can be identified. Concerning the assessment of the evaluation results or the success of the projects, it can be assumed that the participating students are characterized by a fundamental willingness to open up to other living environments. They already bring social commitment with them, as otherwise participation in one of the sponsorship projects would probably not be sought. Regarding the deficiency perspective of the mentees, which is often taken up by the students at the beginning of the projects, it must be considered that these perspectives and expectations may be conveyed by the project itself. The initial design of the sponsorship projects is exclusionary, considering that disadvantaged children or children "in special circumstances" are explicitly addressed as such. This is true despite an increase in the participation of the children involved and the inclusive objective which is being pursued. In essence, an attempt for inclusion is made through a measure which initially exhibits an exclusionary character.

\section{SUMMARY AND CONCLUSION}

Throughout the sponsorships, students have the opportunity to get to know the heterogeneous living environments of the children. The students come into direct contact with various dimensions of inequality and aspects of diversity. Additionally, experiences are gained within the context of the cooperation required in the project. These practical experiences are underpinned with theoretical knowledge in the seminar where reflections are stimulated, as in the supervision. An ethnographic research approach is introduced and a differentiated case analysis required to promote a scientific handling of the observations made in the children's living environment. The results of the evaluation of the sponsorship projects so far indicate that the students especially reflect biographical and self-referential, but also structural-theoretically. These two perspectives of reflection complement each other and integrate knowledge offered in the seminar. The analyses to-date show that, students adopt inclusive attitudes over the course of the projects, in the sense that deficiency perspectives and attributions of normality are reflected and relativized. The own location-boundedness and the subsequent patterns of thinking and experience contexts are made conscious and are questioned. The mentees are perceived less as disadvantaged during the projects. The mentors open themselves up to the diversity of circumstances and living environments of their mentees and emphasize their individuality and personality. It remains to be seen whether these changed orientations can be integrated into one's habitus in the long term. However, it can be noted that an awareness for inclusive practice is sharpened. Even though the attitude changes are oriented towards the inclusive discourse of the seminar and the students want to conform to presumed expectations therein, the analyses point out that they have better knowledge of the requirements of their future professional field, have experienced the importance of reflections for a successful professional practice and are encouraged to integrate an inclusive orientation into their professional habitus. Irrespective of how the sponsorships proceeded in detail, the evaluation also shows that the students themselves attach great importance to the projects in terms of their personal and professional development.

Although the evaluation has not yet been completed, it can be assumed that the sponsorship projects are suitable to prepare students for an inclusive school setting and able to contribute to the professionalization. 


\section{REFERENCES}

Aeppli, J., \& Lötscher, H. (2016). EDAMA - Ein Rahmenmodell für Reflexion. Beiträge zur Lehrerinnenund Lehrerbildung, 34(1), 78-97.

Ainscow, M., Booth, T., Dyson, A., Booth, T., \& Dyson, A. (2006). Improving schools, developing inclusion. London: Routledge. https://doi.org/10.4324/9780203967157.

Alexi, S., Heinzel, F., \& Marini, U. (2014). Papierfall oder Realfall? Zwei Konzepte der Hochschulbildung im Vergleich. In: I. Pieper, P. Frei, K. Hauenschild, \& B. Schmidt-Thieme. (Hrsg.), Was der Fall ist: Beiträge zur Fallarbeit in Bildungsforschung, Lehramtsstudium, Beruf und Ausbildung (S. 227-241). Wiesbaden: Springer VS.

Alexi, S., Romba, S., \& Heinzel, F. (2016). Mentoring als Lern- und Handlungsfeld in der universitären Lehrerbildung. Journal für Lehrer*innenbildung, 16(2), 60-68.

Andresen, S., \& Neumann, S. (2018). Kinder in Deutschland 2018. 4. World Vision Kinderstudie. Weinheim: Beltz.

Berkemeyer, N., Järvinen, H., Otto, J., \& Bos, W. (2011). Kooperation und Reflexion als Strategie der Professionalisierung in schulischen Netzwerken. In: W. Helsper, \& R. Tippelt. (Hrsg.), Pädagogische Professionalität (S. 225-247). Weinheim: Beltz.

de Boer, H., \& Schwiderski, M. (2018). Professionalisierung durch Mentoring: Studierende unterstützen Flüchtlingskinder. In: S. Miller, B. Holler-Nowitzki, B. Kottmann, S. Lesemann, B. Letmathe-Henkel, N. Meyer, R. Schroeder, \& K. Velten. (Hrsg.), Profession und Disziplin: Grundschulpädagogik im Diskurs (S. 246-251). Wiesbaden: Springer VS.

Boller, S. (2012). Multiprofessionalität als Weg der Schulentwicklung? Möglichkeiten und Grenzen berufsfeldübergreifender Zusammenarbeit in der Schule. In: S. Huber, \& F. Ahlgrimm. (Hrsg.), Kooperation. Aktuelle Forschung zur Kooperation in und zwischen Schulen sowie anderen Partnern (S. 203222). Münster u.a.: Waxmann.

Breidenstein, G., Hirschauer, S., Kalthoff, H., \& Nieswand, B. (2015). Ethnografie - Die Praxis der Feldforschung (2. Aufl.). Konstanz: UTB.

Combe, A., \& Kolbe, F.-U. (2008). Lehrerprofessionalität - Wissen, Können, Handeln. In: W. Helsper, \& J. Böhme. (Hrsg.), Handbuch der Schulforschung (2. erweiterte Aufl., S. 857-876). Wiesbaden: VS Verlag für Sozialwissenschaften.

Erhardt, M., \& Breyer, C. (2013). Inklusive Schule gestalten durch inklusive Lehrerbildung. Zeitschrift für Inklusion. https://www.inklusion-online.net/index.php/inklusion-online/article/view/197.

Fabel-Lamla, M. (2006). Prozesse der Biographisierung und Professionalisierung bei ehemaligen DDRLehrerinnen und -Lehrern nach 1989/90.. In Bukow, W.-D., Ottersbach, M., Tuider, E., \& Yildiz, E. (Hrsg..), Biographische Konstruktionen im multikulturellen Bildungsprozess. Individuelle Standortsicherung im globalisierten Alltag (= Interkulturelle Studien, Bd. 18) (S. 83-98). Wiesbaden: Verlag für Sozialwissenschaften.

Fabel-Lamla, M. (2018). Der (berufs-)biographische Professionsansatz zum Lehrerberuf. Zur Relevanz einer biographischen Perspektive in der Lehrerbildung. In: J. Böhme, C. Cramer, \& C. Bressler. (Hrsg.), Erziehungswissenschaft und Lehrerbildung im Widerstreit!? Verhältnisbestimmungen, Herausforderungen und Perspektiven (S. 82-100). Bad Heilbrunn: Julius Klinkhardt.

Fabel-Lamla, M., \& Reinecke Terner, A. (2015). Schulsozialarbeit im inklusiven Schulsystem - Chancen und Herausforderungen der Kooperation in multiprofessionellen Teams. In C. Krüger, \& Mähler, R. M. 
(Hrsg..), Gemeinsames Lernen in inklusiven Klassenzimmern. Prozesse der Schulentwicklung gestalten (pp. 147-156). Köln: Carl Link.

Frey, A., \& Buhl, H. M. (2018). Professionalisierung von Grundschullehrkräften - wissenschaftlich fundiert, praxisorientiert und reflexionsbasiert. Zeitschrift für Grundschulforschung, 11(2), 199-213.

Friebertshäuser, B., \& Panagiotopoulou, A. (2010). Ethnographische Feldforschung. In Friebertshäuser, C., Langer, A., \& Prengel, A. (Hrsg..), Handbuch Qualitative Forschungsmethoden in der Erziehungswissenschaft (S. 301-322). Weinheim und München: Juventa Verlag.

Garlichs, A., Petersen, J., \& Reinert, G. B. (2000). Schüler verstehen lernen: Das Kasseler Schülerhilfeprojekt im Rahmen einer reformorientierten Lehrerausbildung. Donauwörth: Auer.

Geertz, C. (1983). Dichte Beschreibung. Beiträge zum Verstehen kultureller Systeme. Frankfurt am Main: Suhrkamp.

Gomolla, M. (2003). Fördern und Fordern allein genügt nicht! Mechanismen institutioneller Diskriminierung von Migrantenkindern und -jugendlichen im deutschen Schulsystem. In: G. Auernheimer. (Hrsg.), Schieflagen im Bildungssystem. Die Benachteiligung der Migrantenkinder (S. 87-101). Wiesbaden: Springer VS.

Häcker, T. (2017). Grundlagen und Implikationen der Forderung nach Förderung von Reflexivität in der Lehrerinnen- und Lehrerbildung. In: C. Berndt, T. H. Häcker, \& T. Leonhard. (Hrsg.), Reflexive Lehrerbildung revisited: Traditionen - Zugänge - Perspektiven (S. 21-45). Bad Heilbrunn: Julius Klinkhardt.

Häcker, T. H., Berndt, C., \& Walm, M. (2016). Reflexive Lehrerinnen- und Lehrerbildung in ,inklusiven Zeiten'. In: B. Amrhein. (Hrsg.), Diagnostik im Kontext inklusiver Bildung. Theorien, Ambivalenzen, Akteure, Konzepte (S. 261-278). Bad Heilbrunn: Julius Klinkhardt.

Häcker, T., \& Walm, M. (2015). Inklusion als Herausforderung an eine reflexive Erziehungswissenschaft. Anmerkungen zur Professionalisierung von Lehrpersonen in "inklusiven" Zeiten. Erziehungswissenschaft, 26(51), 81-89.

Heinrich, M., Urban, M., \& Werning, R. (2013). Grundlagen, Handlungsstrategien und Forschungsperspektiven für die Ausbildung und Professionalisierung von Fachkräften für inklusive Schule. In: H. Döbert, \& H. Weishaupt. (Hrsg.), Inklusive Bildung professionell gestalten. Situationsanalyse und Handlungsempfehlungen (S. 69-133). Waxmann: Münster u.a.

Heinzel, F. (2007). Fallarbeit und Fallstudien in der Lehrerbildung. Zugang zum Denken und Handeln von Kindern. In: F. Heinzel, A. Garlichs, \& S. Pietsch. (Hrsg.), Lernbegleitung und Patenschaften: Reflexive Fallarbeit in der universitären Lehrerausbildung (S. 146-156). Bad Heilbrunn: Julius Klinkhardt.

Heinzel, F., \& Garlichs, A. (2007). Lehrerausbildung und Schulpädagogik vor neuen Aufgaben. In: F. Heinzel, A. Garlichs, \& S. Pietsch. (Hrsg.), Lernbegleitung und Patenschaften: Reflexive Fallarbeit in der universitären Lehrerausbildung (S. 11-20). Bad Heilbrunn: Julius Klinkhardt.

Heinzel, F., Garlichs, A., \& Pietsch, S. (Hrsg.). (2007). Lernbegleitung und Patenschaften: Reflexive Fallarbeit in der universitären Lehrerausbildung. Bad Heilbrunn: Julius Klinkhardt.

Heise, C., \& Heinzel, F. (2020). Patenschaftsprojekte in der Lehrerinnenbildung - Fallarbeit im Spannungsfeld von inklusivem Anspruch und exkludierender Praxis. In M. Fabel-Lamla, K. Kunze, A. Moldenhauer, \& Rabenstein, K. R. (Hrsg..), Kasuistik - Lehrer_innenbildung - Inklusion. Empirische und theoretische Verhältnisbestimmungen. Bad Heilbrunn: Julius Klinkhardt.

Helsper, W. (1996). Antinomien des Lehrerhandelns in modernisierten pädagogischen Kulturen: Paradoxe Verwendungsweisen von Autonomie und Selbstverantwortlichkeit. In: A. Combe, \& W. Helsper. (Hrsg.), Pädagogische Professionalität (S. 521-569). Frankfurt a.M.: Suhrkamp. 
Helsper, W. (2002). Lehrerprofessionalität als antinomische Handlungsstruktur. In: M. Kraul, W. Marotzki, \& C. Schweppe. (Hrsg.), Biographie und Profession (S. 62-102). Bad Heilbronn: Julius Klinkhardt.

Herzog, W. (1995). Reflexive Praktika in der Lehrerinnen- und Lehrerbildung. Beiträge zur Lehrerbildung, 13(3), 235-273.

Herzog, S. (2011). Über den Berufseinstieg hinaus: Berufsbiografien von Lehrerinnen und Lehrern im Blickfeld der Forschung. In: E. Terhart, H. Bennewitz, \& M. Rothland. (Hrsg.), Handbuch der Forschung zum Lehrerberuf (S. 314-338). Waxmann: Münster u.a.

Hochschulrektorenkonferenz \& Hochschulkonferenz (2015). Lehrerbildung für eine Schule der Vielfalt. Gemeinsame Empfehlung von Hochschulkonferenz und Kultusministerkonferenz. Beschluss der Kultusministerkonferenz vom 12.03.2015/Beschluss der Hochschulkonferenz vom 18.03.2015. https:// www.kmk.org/fileadmin/Dateien/veroeffentlichungen_beschluesse/2015/2015_03_12-Schule-derVielfalt.pdf.

Katzenbach, D. (2015). Zu den Theoriefundamenten der Inklusion-eine Einladung zum Diskurs aus der Perspektive der kritischen Theorie. In: I. Schnell. (Hrsg.), Herausforderung Inklusion. Theoriebildung und Praxis (S. 19-32). Bad Heilbrunn: Julius Klinkhardt.

Konferenz K. (2014). Standards für die Lehrerbildung: Bildungswissenschaften. Fassung vom 12. Juni 2014. https://www.kmk.org/fileadmin/Dateien/veroeffentlichungen_beschluesse/2004/2004_12_16-StandardsLehrerbildung-Bildungswissenschaften.pdf.

Korthagen, F. A. J., \& Vasalos, A. (2005). Levels in reflection: Core reflection as a means to enhance professional growth. Teachers and Teaching, 11(1), 47-71.

Korthagen, F. A. J., \& Vasalos, A. (2010). Going to the core: Deepening reflection by connecting the person to the profession. In: N. Lyons. (Hrsg.),Handbook of reflection and reflective inquiry (S. 529-552). Wiesbaden: Springer.

Kottmann, B. (2014). "Schule für alle" - ein Projekt zur Förderung fachlicher und überfachlicher Kompetenzen. In: C. Rohlfs, M. Harring, \& C. Palentien. (Hrsg.), Kompetenz-Bildung: Soziale, emotionale und kommunikative Kompetenzen von Kindern und Jugendlichen (S. 375-384). Wiesbaden: Springer VS.

Lange-Vester, A., \& Teiwes-Kügler, C. (2014). Habitussensibilität im schulischen Alltag als Beitrag zur Integration ungleicher sozialer Gruppen. In: T. Sander. (Hrsg.), Habitussensibilität. Eine neue Anforderung an professionelles Handeln (S. 176-207). Wiesbaden. Springer VS.

Kramer, R. T. (2015). Dokumentarische Methode und Objektive Hermeneutik im Vergleich. Zugleich ein Versuch der Schärfung der Rekonstruktionsmethodologie. Sozialer Sinn, 16(2), 171-197.

Kramer, R. T. (2017). Sequenzanalytische Habitusrekonstruktion. Methodologische Überlegungen zu einer neuen Methode der Habitushermeneutik. In Heinrich, M., \& Wernet, A. (Hrsg..), Rekonstruktive Bildungsforschung. Zugänge und Methoden (S. 243-267). Wiesbaden: Springer.

Lange, J., \& Wiesmann, J. (2012). Ethnographie. In: F. Heinzel. (Hrsg.), Methoden der Kindheitsforschung: Ein Überblick über Forschungszugänge zur kindlichen Perspektive (2. überarbeitete Aufl., S. 262-277). Weinheim u.a.: Beltz Juventa.

Löser, J. M., \& Werning, R. (2015). Inklusion - allgegenwärtig, kontrovers, diffus? Erziehungswissenschaft, 26(2), 17-24.

Lotze, M., \& Kiso, C. (2014). Von der Aufgabe, eine Haltung zu entwickeln-Zwischen ideellen und strukturellen Anforderungen innerhalb der Diskurse um individuelle Förderung, Inklusion und Begabungsförderung. In: C. Schwer, \& C. Solzbacher. (Hg.), Professionelle pädagogische Haltung. Historische, theoretische und empirische Zugänge zu einem viel strapazierten Begriff (S. 157-172). Bad Heilbrunn: Julius Klinkhardt. 
Lüsebrink, I., \& Grimminger, E. (2014). Fallorientierte Lehrer/innenausbildung evaluieren - Überlegungen zur Modellierung von unterrichtsbezogener Reflexionskompetenz. In: I. Pieper, P. Frei, K. Hauenschild, \& B. Schmidt-Thieme. (Hrsg.), Was der Fall ist. Beiträge zur Fallarbeit in Bildungsforschung, Lehramtsstudium, Beruf und Ausbildung. (S. 201-211). Wiesbaden: Springer VS.

Maas, M. (2007). Das essener Schülerhilfeprojekt. In: F. Heinzel, A. Garlichs, \& S. Pietsch. (Hrsg.), Lernbegleitung und Patenschaften. Reflexive Fallarbeit in der universitären (S. 43-61). Bad Heilbrunn: Julius Klinkhardt.

Mayring, P. (2010). Qualitative Inhaltsanalyse. In: G. Mey, \& K. Mruck. (Hrsg.), Handbuch Qualitative Forschung in der Psychologie. (S. 601-613). Wiesbaden: Springer VS.

Müller-Kohlenberg, H. (2018). Handbuch Mentoring für Grundschulkinder. Balu und Du. 53 Bausteine für Theorie und Praxis. Ibbenbüren: Klaus Münstermann.

Panagiotopoulou, A., \& Winter, J. (2019). Ungleichheiten im Bildungssystem: Übergänge als Bildungsbarrieren? In: M. Dziak-Mahler, A. Krämer, R. Lehberger, \& T. Matthiesen. (Hrsg.), Weichen stellen Chancen eröffnen. Studierende begleiten Viertklässler im Übergang zur weiterführenden Schule (S. 5572). Münster u.a.: Waxmann.

Pieper, I., Frei, P., Hauenschild, K., \& Schmidt-Thieme, B. (Hrsg.). (2014). Was der Fall ist. Was der Fall ist. Beiträge zur Fallarbeit in Bildungsforschung, Lehramtsstudium, Beruf und Ausbildung. Wiesbaden: Springer VS.

Pietsch, S. (2009). Forschendes Lernen im Rahmen des "Projekt K - Kinder begleiten und verstehen lernen”. In: B. Roter, R. Schneider, B. Koch-Priewe, J. Thiele, \& J. Wildt. (Hrsg.), Forschendes Lernen im Lehramtsstudium. Hochschuldidaktik, Professionalisierung, Kompetenzentwicklung (S. 151-174). Bad Heilbrunn: Julius Klinkhardt.

Pietsch, S. (2010). Begleiten und begleitet werden: Praxisnahe Fallarbeit - Ein Beitrag zur Professionalisierung in der universitären Lehrerbildung. Kassel: Kassel University Press.

Reichertz, J. (2014). Die Fallanalyse als soziale Praxis der Lehrerbildung. In: I. Pieper, P. Frei, K. Hauenschild, \& B. Schmidt-Thieme. (Hrsg.), Was der Fall ist. Beiträge zur Fallarbeit in Bildungsforschung, Lehramtsstudium, Beruf und Ausbildung. (S. 19-35). Wiesbaden: Springer VS.

Schön, D. A. (1984). The reflective practitioner: How professionals think in action. New York: Basic Books.

Schwer, C., \& Solzbacher, C. (Hg.). (2014). Professionelle pädagogische Haltung: Historische, theoretische und empirische Zugänge zu einem viel strapazierten Begriff. Bad Heilbrunn: Julius Klinkhardt.

Schwer, C., Solzbacher, C., \& Behrensen, B. (2014). Annäherung an das Konzept "Professionelle pädagogische Haltung": Ausgewählte theoretische und empirische Zugänge. In: C. Schwer, \& C. Solzbacher. (Hg.), Professionelle pädagogische Haltung. Historische, theoretische und empirische Zugänge zu einem viel strapazierten Begriff (S. 47-77). Bad Heilbrunn: Julius Klinkhardt.

Terhart, E. (2011). Lehrerberuf und Professionalität. Gewandeltes Begriffsverständnis - neue Herausforderungen In W. Helsper, \& R. Tippelt. (Hrsg.), Pädagogische Professionalität(S. 202-224). Weinheim u.a.: Beltz (Zeitschrift für Pädagogik, Beiheft; 57). https://doi.org/10.1007/978-3-663-099888 8.

Terhart, E. (2013). Erziehungswissenschaft und Lehrerbildung. Waxmann: Münster.

Tillmann, K.-J. (2007). Viel Selektion - wenig Leistung. Ein empirischer Blick auf Erfolg und Scheitern in deutschen Schulen. In: D. Fischer. (Hrsg.), Zur Gerechtigkeit im Bildungssystem (S. 25-37). Waxmann: Münster o.a. 
Wenzler-Cremer, H. (2016). Studierende und Kinder lernen voneinander: Ein Patenschaftsprogramm. Freiburg i.B.: Lambertus-Verlag.

Wyss, C. (2013). Unterricht und Reflexion. Eine mehrperspektivische Untersuchung der Unterrichts- und Reflexionskompetenz von Lehrkräften. Waxmann: Münster u.a. Uncited References

Open Access. This is an open-access article distributed under the terms of the Creative Commons Attribution-NonCommercial 4.0 International License (https://creativecommons.org/licenses/by-nc/4.0/), which permits unrestricted use, distribution, and reproduction in any medium for non-commercial purposes, provided the original author and source are credited, a link to the CC License is provided, and changes - if any - are indicated. 